\title{
INSURANCE MARKET OF UZBEKISTAN AND NEED FOR MUTUAL INSURANCE COMPANIES
}

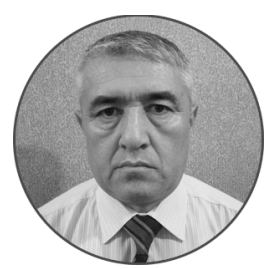

Article history:

Received 3 October 2017 Received in revised form 1 November 2017 Accepted 18 January 2018 Translated 13 June 2018 Available online 27 June 2018

JEL classification: G2, G22

Keywords: insurance services, insurance market, insurance premium, mutual insurance, commercial insurance

\author{
Kamariddin M. KULDASHEV \\ Tashkent Financial Institute, Tashkent, Republic of Uzbekistan \\ KuldashevKM@gmail.com
}

\begin{abstract}
Importance The article reviews mutual insurance, its distinctions, advantages and demand for it in Uzbekistan. Objectives The research determines the position of Uzbekistan's insurance market and identifies its development issues. I substantiate advantages of mutual insurance and benefits if it is implemented in certain sectors of the economy, including agriculture.

Methods The methodological underpinning comprises basic research in insurance. The research employs structural, logic and systems approaches.

Results I analyze and compare the current situation in Uzbekistan's insurance market and those in other countries. Drawing upon the previous research, I determine distinctions of the situation, weaknesses and issues of Uzbekistan's insurance market. The article also points out general and specific traits of mutual and commercial insurance, emphasizing the advantage of mutual insurance. Mutual insurance companies seem to be one of the development solutions for the insurance market, especially in case of agriculture.

Conclusions and Relevance Based on the findings, I provide my recommendations for developing the insurance market and improving the quality of services. To ensure the concurrent promotion of the insurance market and commercial insurance, mutual insurance should be introduced in agriculture.
\end{abstract}

๑) Publishing house FINANCE and CREDIT, 2017

The editor-in-charge of this article was Irina M. Vechkanova

Authorized translation by Irina M. Vechkanova

Insurance is a crucial element of an economic system. Its future development will unavoidably induce reforms of the entire economic system. Insurance implies that entities accumulate a portion of their assets and use them to recover losses from unfavorable weather conditions and other risks. There is no other sector like insurance where the State plays such a decisive role. The State performs insurance functions and oversees respective operations. Insurance is so sensitive due to its public importance. Any insurable event is often

${ }^{\dagger}$ For the source article, please refer to: Кулдашев К.М. Страховой рынок Узбекистана и необходимость создания взаимных страховых обществ. Экономический анализ: теория и практика. 2018. Т. 17. № 4. C. 690-703.

URL: https://doi.org/10.24891/ea.17.4.690 perceived as a catastrophe for the insured, thus giving rise to an insurable event in the national economy, and production chain gap.

Entering into an insurance contract, the insured can recover its property status quite quickly, mend disrupted business relations ties for reproduction. Considering the global nature of insurance, reinsurance and globalized economic processes in particular, it is necessary to examine each functional part of the Uzbek economic system from global perspectives.

Scholars conducted multiple studies into the role of insurance, including mutual insurance in economic and social development. Some researches determine 
the position and functional role of mutual insurance in the modern insurance market, i.e.:

- mutual insurance is justified as a method for creating competitive products in the insurance market, outlining effective approaches to insurance against various risks in sectors of the modern economy [1];

- the initial pool of mutual insurance companies' funds constitutes organizational costs, guarantee capital and production capital for mutual insurance companies to cover losses and incur current expenditures respectively ${ }^{1}$;

- mutual insurance companies are proved to deliver insurance services of higher quality to its members for an affordable price by applying the reduced structure of gross insurance premium under an insurance plan [2];

- analysis covered sources of insurance law, conceptual framework, protection of customers' rights with respect to insurance companies, insurance companies, insurance process, insurance of property, responsibility and reinsurance [3];

- activities of insurance companies are analyzed from perspectives of political economy, finance, governance, law and accounting [4];

- substance of mutual insurance is unveiled [5].

The insurance market originated not so long ago in Uzbekistan. The Law On Insurance was adopted in the Republic of Uzbekistan in 1993. In 2002, the new Law On Insurance Activity was enacted, still being effective. Moreover, dozens of rules and regulations on insurance were passed.

Compulsory insurance is on the upswing. This rise resulted from laws on compulsory liability insurance of car owners (2008), employers (2009) and carriers (2015). The Uzbek insurance companies raise the volume of insurance premiums every year. There is a persistent declining trend in insurance premium concentration, i.e. insurance activities continue to grow in the regions of Uzbekistan.

It is getting clear that insurance is one of the rapidly growing industries in the Republic of Uzbekistan. However, insurance evolves not so fast as it should to

\footnotetext{
${ }^{1}$ Strakhovoe delo. V 2 tomakh. T. 1 [Insurance. Two Volumes. Volume One]. Moscow, Ekonomist Publ., 2004, 447 p.
}

increase its potential in the overall economy. Insurance still makes little contribution to the national economic development. The percentage of the insurance sector has been accounting for 0.3-0.4 percent of GDP for 10-15 years (Table 1). It is several times as high as in the European countries, USA and Japan (8-12 percent). Unfortunately, despite a fast pace of growth, insurance is not able to catch up with rapidly rising macroeconomic indicators of Uzbekistan.

Insurance has not yet occupied its niche in the Uzbek economy. People and business are reluctant to deal with insurance companies, having little confidence in them. The potential insured are not certain that they will receive insurance coverage on a timely basis in case of insurance events. This statement is corroborated with the fact that insurance coverage of insurable events accounts for 18 percent of total insurance premiums collected by insurers for a year (Table 2).

The government provides aid and tax incentives to the insurance sector. However, as I see it, insurance companies' performance, information on new products, strategic plans for relations with customers and market actors leave much to be desired.

The insurance market experience a high concentration of actors. In particular, over 55 percent of total insurance premiums are held by only five major companies of Uzbekistan, and 76 percent in case of 10 companies respectively (Table 3).

What else distinguishes the insurance sector is that there are no regional insurance companies in Uzbekistan. Almost all of them are registered in Tashkent, the capital of Uzbekistan. However, this disadvantage is compensated with multiple regional representatives of the companies. I believe the issue cannot be totally resolved this way. Regional insurance market has the potential for further development.

The State has been paying much attention to business for the recent years. Business increased its share in GDP, concurrently experiencing a rise in business risks. Businessmen's attitude to insurance remains almost unchanged. Insurance companies also overlook the business sector. For example, neither insurance company has an insurance contract for production disruption. In the mean time, this type of insurance became quite common abroad long ago. 
Having analyzed multiple statistical and descriptive materials, I found a number of alternative ways for insurance development. In Uzbekistan, as part of the State-as-the-main-reformer initiative, there are many benefits for streamlining and developing commercial insurance. Substantial support of the State can be proved by comparing data with insurance preferences and benefits in the CIS countries.

Ensuring priority development of insurance in comparison with GDP, it is necessary for the State to develop and implement alternative options of insurance based mainly on moral principles. Insurance benefits the State grants shall also be effectively utilized.

Long-standing confidence of the public can be won by developing absolutely new insurance products, which would provide tangible and financial advantages for the insurers and insured. It is also very important to adhere to the principle of equal financial rights, interest of all the parties in the ultimate goal.

Following this course, it is crucial to reasonably exercise the existing legislative framework. For example, Article 960 of the Civil Code of the Republic of Uzbekistan Mutual Insurance is still pending.

To set up and run mutual insurance companies in Uzbekistan, even this document will be initially enough to address the issue. Later on there should be articulated and adopted the new law On Mutual Insurance.

Agricultural insurance is one of the insurance segments that is almost absent in Uzbekistan.

The agricultural sector enters a new phase of its development, striving to higher quality and competitiveness of products, assuming an innovative course, i.e. technical and technological retrofitting and renewal, decentralized governance, improvement of market relations and increase in the export potential of the sector and profits of agricultural producers.

Agricultural insurance is voluntary in Uzbekistan. Voluntary insurance unfolds rather slowly because agricultural producers lack available funds to make insurance contributions and understanding of insurance as a mechanism for farmers to protect their financial well-being.

Considering the expertise of other countries, there shall be formulated a law on agricultural risk insurance, which would define the legislative principles and specifics of insurance of agricultural risks, apply to agricultural property and harmonize the Uzbek laws on agriculture. The law should pursue the creation and maintenance of political, economic, social, environmental and legislative conditions for profitable performance of agricultural enterprises, increased profit of farms, development of market relations, economic and food security, strengthening of the Uzbek agricultural sector.

Mutual insurance may become the best-fit method to promote insurance in agriculture and other segments. This insurance option will allow to reduce insurance premiums, on the one hand, and raise the confidence of the insured. That is why the law should envisage this type of insurance in agriculture.

Mutual insurance is one of the insurance protection forms. Local people provide voluntary and public support to each other for centuries, when people help one of the community members on a regular basis so as to improve his or her socio-economic position. Such actions are called Hashar (Arabic word meaning 'charity'). In fact, mutual insurance principles are based on such concepts to a certain extent.

Unlike profit-making insurance companies, mutual insurance companies do not pursue profit. That is why all their reserves are kept by the founders, i.e. the insured.

Historically, the insurer and insured are the same person, thus constituting the first organizational form of mutual insurance and conveying its non-profit nature ${ }^{2}$.

As part of mutual insurance and protection of property interests, community members combine their money to make a pool of insurance funds. The right of each insured morphs into a right of joint ownership pertaining to the entire community of insured/insurers [6]. What distinguishes mutual insurance is that each insured, as a stakeholder, actively participates in administrative, financial activities of the community and has a voting right. Members of mutual insurance company can determine the company development policy, risks subject to insurance coverage, cost of services, formation of insurance reserves, etc. Tangible resources may be merged with resources of other

\footnotetext{
${ }^{2}$ Pinkin Yu.V. Spravochnik strakhovshchika [Insurer's Handbook]. Rostov-on-Don, Feniks Publ., 2007, 173 p.
} 
insured that have a similar intention to insure property interests. Such a combination takes place upon consent of the stakeholders. To create insurance products, the stakeholders make contributions to a pool of insurance funds, with each of them keeping the ownership right to the funds [7].

The main provisions of the theory of eventual needs were logically complemented by A. Manes, the German scholar who put the money saving mechanism to the forefront of the insurance theory since it allowed for contribution-based participation of many persons [8].

Scrutinizing the indicia that define the mutual nature of insurance relations, many researchers underlined, first, the equal position of the insured, second, participation of the insured in their mutual insurance company management, third, the so called solidarity ties that unite the members on the reciprocity principles [9].

The reciprocal responsibility of the community members for their insurance activity is one of the fundamental economic principles [10].

Even the State puts the national solidarity and reciprocity at the basis of the national insurance system. For example, France. There every resident pays an equal insurance premium no matter whether he or she is exposed to a risk, thus contributing to insurance coverage of those residents who live in areas exposed to various insurance risks [11].

Regular preventive measures are the main tool to decrease the amount of an individual contribution. Hence mutual insurance companies often resort to preventive actions as one of the main organizational measures.

The process is different in joint-stock companies. According to the Russian analysts, joint-stock company almost neglect preventive measures to reduce their risks and avoid insurable events. As a result of non-existent preventive actions, insurable events cause greater damage and detriment to the inflicted persons and subsequently inhibit the overall economic growth [12]. Currently, the same situation is observed in the national insurance market of Uzbekistan occupied by profit-making insurance companies only.

Initial phases of mutual insurance actually witnessed the fold-insurance system implying that the community members were not supposed to make contributions but equally shared losses and expenses in case of insurable events. As economic relationships evolved, the foldinsurance system gradually transformed into a preliminary payment system. The mutual insurance method originated in the life insurance segment, since the reciprocity method was easier to implement in personal insurance, rather than property one [13].

As seen in practice, the form of mutual insurance in the USA, Japan and some European countries is not less significant and effective than its profit-making format. Currently, six in ten wealthiest insurance companies pertain to the mutual insurance segment ${ }^{3}$, with two of them operating in Japan (Table 4). The Japanese insurance market goes second in the world after the USA by amount of insurance premiums. The Japanese life insurance market accounts for about 16 percent of total insurance premiums collected in the segment worldwide ${ }^{4}$.

Nowadays, mutual insurance turns into a global phenomenon. Mutual insurance companies occupy a special niche in markets of most industrially advanced nations.

Such mutual insurance as Takaful is rather well developed in many Muslim countries. This financial tool helped not only accumulated idle resources within countries but also diversify the global financial market.

There are countries promoting the Takaful development as an alternative insurance mechanism that are in agreement with the Sharia laws and ethics [14].

Takaful, or Islamic insurance, represents a system based on mutual help principles (Taawun) and voluntary donations (Tabarru), which calls for joint and voluntary allocation of risks among the community members. Takaful constitutes a form of insurance which is

\footnotetext{
${ }^{3}$ Resolyutsiya II Mezhdunarodnoi nauchno-prakticheskoi konferentsii po srakhovaniyu v Rossiskom ekonomicheskom universitete im. G.V. Plekhanova Vzaimnoe strakhovanie: mirovye tendetsii I perspektivy razvitiya $v$ Rossii [Resolution of the 2 nd International Scientific and Practical Conference on Insurance in the Plekhanov Russian University of Economics ' Mutual Insurance: International Trends and Development Prospects in Russia]. URL: http://finvector.ru/wpcontent/uploads/2012/04/\%D0\%98\%D0\%BD\%D1\%84\%D0\%BE \%D1\%80\%D0\%BC\%D0\%B0\%D1\%86\%D0\%B8\%D0\%BE\%D0\%BD\%D0\%BD \%D0\%BE\%D0\%B5-\%D1\%81\%D0\%BE\%D0\%BE

\%D0\%B1\%D1\%89\%D0\%B5\%D0\%BD\%D0\%B8\%D0\%B5.pdf (In Russ.)

${ }^{4} J a p a n ' s$ Insurance Markets: A Sea of Change. Swiss Reinsurance Company Economic Research and Consulting. SwissRe. Sigma, 2000.
} 
compliant with the Islamic law, meaning reciprocal guarantee in Arabic ${ }^{5}$.

Takaful lays the basis for a new line of global insurance development. Considering that the majority of the Uzbek population are Muslims, I believe it would be reasonable to introduce Takaful into the insurance system of Uzbekistan.

Some advantage of mutual insurance companies stems from the status of profit-making companies, which do not pay income tax since it does not exist as is. That is why their tariffs are lower than insurance companies offer. The difference between mutual insurance and profit-making companies are presented in Table 5.

Mutual insurance companies provide coverage only for their own members. The insured of the mutual insurance company acts as its member at the same time. A member of the mutual insurance company is not its shareholder, fund investor or stakeholder since the mutual insurance company sets up a joint-stock capital (unit investment, pooled capital) or other types of capital divided in unit investments or shares, without forming authorized capital (non-profit companies do not have authorized capital).

Agriculture is one of the most promising areas for mutual insurance.

Agriculture is a strategic sector of the economy. Its effective development mainly depends on the extent to which the State interferes into its management, and amount of the State aid. The State often uses insurance as one of the methods to economically influence the agricultural sector and recover losses of agricultural producers in case of natural risks.

Uzbekistan draws on hand-on experience of agricultural insurance in industrially advanced countries. There the State supports agricultural businesses through market mechanisms of insurance, being a component of the governmental policy in agriculture.

In other countries the State provides subsidies for insurance premiums of agricultural insurance companies, reimburses damages, arranges for the governmental system of reinsurance on

\footnotetext{
${ }^{5}$ Engku Rabian Adaviah Engku Ali, Odierno Hassan Scott P. Essential Guide to Takaful (Islamic Insurance). Kuala Lumpur, Malaysia, CERT Publication Sdn. Bhd., 2008.
}

a commercial and gratuitous basis in domestic and foreign markets [15].

Following the expertise of developed countries, mutual insurance companies could play a special role in agriculture of Uzbekistan, being virtually a form of agricultural cooperation.

Mutual insurance suits farming because it rests upon ideas of community and mutual help, which are traditional for the Uzbek mentality. This may drive farmers into the insurance sector.

As globally observed, mutual insurance may become the most powerful and protective shield from most agricultural risks. Putting up a part of their funds together within a mutual insurance company, farmers do not have to give their money to someone else.

There are few insured farms in Uzbekistan so far. This especially affects farmers in years of poor crops, undermines the stability of agricultural production. The abolishment of compulsory insurance of agricultural crops eroded this type of insurance within the total volume of insurance in Uzbekistan.

Proceeds from agricultural crop insurance decreased tenfold [16]. Such a negative effect can be overwhelmed by setting up mutual insurance companies. The State should financially support farmers who participate in mutual insurance companies at least by paying some of their insurance contributions. Budgetary backing can be crucial in the emergence of agricultural mutual insurance companies which mainly cease to develop due to limited finance.

Any agricultural mutual insurance company reasonably needs to quickly erect the vertical structure at the regional and even republican level. If there is a republican system of mutual insurance companies in agriculture, this will allow to reallocate risks throughout a considerable area, thus making mutual insurance companies more sustainable. They could provide coverage in case of droughts, floods, poor crops. Insurance coverage has a little share in total insurance premiums in the national market today. Referring to the USA, EU and Japan, the indicator is expected to reach at least 80 percent of total insurance premium, which is the main advantage of mutual insurance in comparison with commercial one.

Please cite this article as: Kuldashev K.M. Insurance Market of Uzbekistan and Need for Mutual Insurance Companies. Digest Finance, 2018, vol. 23, iss. 2, pp. 221-229. 
At the current phase of economic development, insurance gets more significant since business activities are influenced by destabilizing transformation, economic and environmental processes. Insurance markets of developed and developing countries demonstrate contradictory development trends. They stem from the global financial and economic crisis and its effect on national production, lower income, response of national economies to new development challenges.

It is worth mentioning that insurance has been stable in Uzbekistan for several recent years in terms of the composition of insurance market actors and components of insurance activities.

I should note some positive trends. The State intervenes insurance activities less frequently, while the regional network of branches expands. What brings hopes is a growth in the number of private companies in insurance. The regional insurance market demonstrates some growth in investing activities. However, some growth in the market volume was offset with inadequate changes in quality:

- low key performance indicators of insurance (percentage of insurance premium in GDP, insurance coverage of GDP);

- poor quality of investment mix and regional disparities in investment;

- life insurance accounts for a little share in the overall insurance portfolio.
Insurance community in Uzbekistan shall be prepared for an arduous work in order to cultivate market relations in the segment. Moreover, it is necessary to create conditions for quality indicators of insurance to grow. Doing so, the market actors should strengthen and expand the base for compulsory insurance, promote all types of agricultural insurance in all the regions of Uzbekistan, various types of voluntary medical insurance. They also should advance the educational level of insurance specialists and develop an appropriate attitude of the population to insurance.

Furthermore, domestic insurance companies should integrate with foreign ones for the sake of further development of the insurance market.

It is also very important to establish mutual insurance companies in different sectors and specifically in agriculture. Mutual insurance companies operate where commercial insurers are reluctant to work due to substantial overhead expenses and small insurance contributions. Therefore, competition should not be regarded as an obstacle since the Uzbek insurance market is not explored yet, being accessible for all willing entrants

Currently, Uzagrosugurta Company is the sole insurance company operating in the agricultural sector. In the mean time, its insurance premiums has been proceedings for the recent years from other types of insurance, rather than from agriculture. It means that the majority of farms still carry on without being insured and protected from risk exposures. 


\section{Table 1}

The share of collected insurance premiums in GDP of the Republic of Uzbekistan

\begin{tabular}{lllll}
\hline Year & GDP, billion UZS & $\begin{array}{l}\text { Insurance premiums, } \\
\text { billion UZS }\end{array}$ & $\begin{array}{l}\text { Percentage of insurance } \\
\text { premiums in GDP }\end{array}$ & Trends, percentage points \\
\hline 2012 & $97,929.3$ & 256.3 & 0.26 & - \\
\hline 2013 & $120,861.5$ & 338.5 & 0.28 & 0.02 \\
\hline 2014 & $145,846.4$ & 439.1 & 0.3 & 0.02 \\
\hline 2015 & $171,808.3$ & 551.5 & 0.32 & 0.02 \\
\hline 2016 & $199,325.1$ & 692.6 & 0.35 & 0.03 \\
\hline
\end{tabular}

Source: Ozbekiston Respublikasi Davlat statistika qo`mitasi. URL: https://stat.uz/uz/

\section{Table 2}

The volume of collected insurance premiums and insurance payments in the insurance market of the Republic of Uzbekistan in 2008-2016

\begin{tabular}{llllllllll}
\hline Indicator & 2008 & 2009 & 2010 & 2011 & 2012 & 2013 & 2014 & 2015 & 2016 \\
\hline $\begin{array}{l}\text { Insurance } \\
\text { premiums } \\
\begin{array}{l}\text { collected, } \\
\text { billion UZS }\end{array}\end{array}$ & 88 & 146.1 & 175.5 & 221.8 & 285.9 & 338.5 & 439.1 & 551.5 & 692.6 \\
\hline $\begin{array}{l}\text { Insurance } \\
\text { payments, } \\
\text { billion UZS }\end{array}$ & 15.5 & 20.7 & 27.6 & 45.1 & 46 & 66.9 & 74.6 & 99.8 & 130.5 \\
\hline $\begin{array}{l}\text { Percentage } \\
\text { of insurance } \\
\text { payments }\end{array}$ & 17.6 & 14,2 & 15.7 & 20.3 & 16.1 & 19.8 & 17 & 18.1 & 18.8 \\
\hline
\end{tabular}

Source: Data of the State Insurance Supervision of the Republic of Uzbekistan

\section{Table 3}

The shares of ten insurance companies in the insurance market of the Republic of Uzbekistan

\begin{tabular}{ll}
\hline Insurance company & Insurance market share, \% \\
\hline Uzagrosugurta & 19.9 \\
\hline Uzbekinvest & 14.5 \\
\hline Kafolat & 10.5 \\
\hline ALSKOM & 5.8 \\
\hline Asia Insurans & 5.1 \\
\hline Alfa Invest & 4.9 \\
\hline Kapital sugurta & 4.9 \\
\hline Ozbekinvest Hayot & 4 \\
\hline Temiryol-Sugurta & 3.7 \\
\hline Agro invest sugurta & 2.9 \\
\hline
\end{tabular}

Source: Data of the State Insurance Supervision of the Republic of Uzbekistan

Please cite this article as: Kuldashev K.M. Insurance Market of Uzbekistan and Need for Mutual Insurance Companies. Digest Finance, 2018, vol. 23, iss. 2, pp. 221-229. 


\section{Table 4}

The number of mutual insurance companies compared to joint stock companies among the ten largest insurance companies

\begin{tabular}{llll}
\hline Company & Country & Assets, billion USD & Legal and business structure \\
\hline AXA & France & 407.9 & Joint-stock company \\
\hline Nippon Life & Japan & 323.3 & Mutual insurance company \\
\hline Allianz & Germany & 293.7 & Joint-stock company \\
\hline Prudential Insurance Company & USA & 259.5 & Mutual insurance company \\
\hline Zenkyoren & Japan & 245.4 & Mutual insurance company \\
\hline Dai-Ichi Mutual Life Insurance & Japan & 219.6 & Mutual insurance company \\
\hline Metropolitan Life & USA & 201.9 & Mutual insurance company \\
\hline American International Group (AIG) & USA & 194.4 & Joint-stock company \\
\hline Sumitomo Life & Japan & 182.6 & Mutual insurance company \\
\hline Prudential & UK & 178.9 & Joint-stock company \\
\hline
\end{tabular}

Source: Pinkin Yu.V. Spravochnik strakhovshchika [Insurer's Handbook]. Rostov-on-Don, Feniks Publ., 2007,173 p.

\section{Table 5}

Specific features of a mutual insurance company (non-profit organization) and an insurance company (profit-making organization)

\begin{tabular}{|c|c|}
\hline Insurance company & Specifics \\
\hline Mutual insurance company & $\begin{array}{l}\text { A non-profit entity aims to ensure the real insurance coverage for its members and promote the social } \\
\text { development as a whole. } \\
\text { Every member of a mutual insurance company is the insurer and insured at the same time, without igniting } \\
\text { any conflict of interests. } \\
\text { Mutual insurance company makes its financial activities transparent for equal members. } \\
\text { Mutual insurance company cannot be bought, sold, split, with the corporate policy depending } \\
\text { on all the members. } \\
\text { Any individual and legal entity can accede the mutual insurance company. According to the corporate policy, } \\
\text { each member is allowed to invest his/her money in insurance plans, propose projects, take an active part } \\
\text { in corporate activities and set up representative offices of the company. } \\
\text { General meeting is the supreme executive body. } \\
\text { All the members constitute the company and have voting rights. } \\
\text { Mutual insurance company is not bound to obtain licenses for its activities and insurance plans. } \\
\text { This preserves corporate flexibility in each particular case so as to satisfy corporate interests. } \\
\text { Mutual insurance company has flexible pricing policy. The price for an insurance service may be lower than } \\
\text { the market average because of the unity of members' goals, low administrative and other expenditures }\end{array}$ \\
\hline Joint stock company & $\begin{array}{l}\text { Profit-making company provides insurance coverage to its customers but also strives to derive as much profit } \\
\text { as possible for shareholders' interests. } \\
\text { The insurer and insured pursue divergent interests due to different goals. } \\
\text { Financial transparency of the company is improbable since it contradicts shareholders' interests } \\
\text { and engenders the risk of customers' confidence loss. } \\
\text { Joint-stock insurance company can be bought, sold, split, with its policy being adaptable to owners } \\
\text { in case of their change. } \\
\text { The clientele may include individuals and legal entities, but they do not participate in outlining insurance } \\
\text { plans, joint projects. } \\
\text { General meeting of shareholders is the supreme executive body in joint stock companies. Its decisions } \\
\text { cannot be argued by customers. } \\
\text { Profit-making insurance company shall obtain license for its activities and each insurance company. } \\
\text { Joint stock companies adhere to a stringent policy of tariffs since the insurers and shareholders' interests } \\
\text { (profit from insurance operations) prevail those of customers }\end{array}$ \\
\hline
\end{tabular}

Source: Pinkin Yu.V. Spravochnik strakhovshchika [Insurer's Handbook]. Rostov-on-Don, Feniks Publ., 2007,173 p. 


\section{References}

1. Logvinova I.L. Vzaimnoe strakhovanie kak metod sozdaniya strakhovykh produktov v rossiiskoi ekonomike [Mutual insurance as a method of creating insurance products in the Russian economy]. Moscow, Ankil Publ., 2010, $246 \mathrm{p}$.

2. Safuanov R., Kashipova I., Ryabchikov A. [On certain directions of economic analysis and performance evaluation of mutual insurance companies]. Strakhovoe delo = Insurance Business, 2009, no. 7, pp. 24-28. (In Russ.)

3. Fogel'son Yu.B. Strakhovoe pravo: teoreticheskie osnovy i praktika primeneniya [Insurance law: Theoretical framework and practical application]. Moscow, Norma Publ., INFRA-M Publ., 2012, 576 p.

4. Grishin A.V. Pravovaya priroda strakhovaniya i organizatsiya strakhovoi deyatel'nosti [The legal nature of insurance and organization of insurance activity]. Orel, Orel Law Institute of the Ministry of Internal Affairs of Russia Publ., 2009, 298 p.

5. Safuanov R.M. Vzaimnoe strakhovanie v Rossiiskoi Federatsii: ekonomiko-organizatsionnye aspekty $i$ analiz stanovleniya [Mutual insurance in the Russian Federation: Economic and organizational aspects and analysis of formation]. Ufa, USAES Publ., 2011, 222 p.

6. Abramov V.Yu. [Mutual insurance companies. Specifics of legal status]. Strakhovoe pravo = Insurance Law, 2005, no. 2, pp. 4-7. (In Russ.)

7. Logvinova I.L. Vzaimnoe strakhovanie v Rossii: osobennosti evolyutsii [Mutual insurance in Russia: Special aspects of evolution]. Moscow, Finansy i statistika Publ., 2009, 175 p.

8. Liker J. Dao Toyota: 14 printsipov menedzhmenta vedushchei kompanii mira [The Toyota Way: 14 Management Principles from the World's Greatest Manufacturer]. Moscow, Al'pina Biznes Buks Publ., 2006, 402 p.

9. Voblyi K.G. Osnovy ekonomii strakhovaniya [Basic concepts of insurance economy]. Moscow, Ankil Publ., 1995, $228 \mathrm{p}$.

10. Dad'kov V.N. [Mutual Insurance Company Management System]. Upravlenie strakhovoi kompaniei = Insurance Company Management, 2007, no. 4, pp. 23-29. (In Russ.)

11. Orishchenko I.V. [Agricultural insurance in European countries and possibilities to use the European experience in Russia]. Sovremennaya ekonomika: problemy i resheniya = Modern Economics: Problems and Solutions, 2010, no. 2, pp. 114-123. (In Russ.)

12. Besfamil'naya L.V., Tavrel' V.S. [Qualitative factors of domestic insurance market growth: Major priorities and ways of improvement]. Strakhovoe delo = Insurance Business, 2009, no. 3, pp. 8-17. (In Russ.)

13. Reikher V.K. Obshchestvenno-istoricheskie tipy strakhovaniya [Socio-historical types of insurance]. Moscow, Yukis Publ., 1992, 282 p.

14. Adamchuk N.G., Dvurechenskikh A.V. [Modern trends in insurance development in Islamic countries]. Strakhovoe delo = Insurance Business, 2015, no. 8, pp. 50-61. (In Russ.)

15. Turbina K.E., Dad'kov V.N. Vzaimnoe strakhovanie [Mutual insurance]. Moscow, Ankil Publ., 2007, 342 p.

16. Mirsadykov M.A., Ashrafkhanov B.B. [Current status and trends in the insurance market Uzbekistan development]. Strakhovoe delo = Insurance Business, 2001, no. 11, pp. 58-64. (In Russ.)

\section{Conflict-of-interest notification}

I, the author of this article, bindingly and explicitly declare of the partial and total lack of actual or potential conflict of interest with any other third party whatsoever, which may arise as a result of the publication of this article. This statement relates to the study, data collection and interpretation, writing and preparation of the article, and the decision to submit the manuscript for publication.

Please cite this article as: Kuldashev K.M. Insurance Market of Uzbekistan and Need for Mutual Insurance Companies. Digest Finance, 2018, vol. 23, iss. 2, pp. 221-229. 